\title{
A review of some key species of mainly Indo-Pacific Ostracoda from the collections of G. S. Brady
}

\author{
ROSEMARY TITTERTON ${ }^{1}$, ROBIN C. WHATLEY ${ }^{2}$ \& JOHN E. WHITTAKER ${ }^{3}$ \\ ${ }^{1}$ Statoil, N-4035 Stavanger, Norway. \\ ${ }^{2}$ Institute of Earth Studies, University of Wales, Aberystwyth SY23 3DB, UK. \\ ${ }^{3}$ Department of Palaeontology, The Natural History Museum, Cromwell Road, London SW7 5BD, UK.
}

\begin{abstract}
Fifteen key species of Recent Ostracoda (all but one from Indo-Pacific waters), selected from the collections of G. S. Brady and deposited in the Hancock Museum, Newcastle-upon-Tyne and The Natural History Museum, London, are reviewed. Holotypes and lectotypes have been formally designated and illustrated (by SEM) in the case of seven of these species: Neonesidea crosskeiana (Brady, 1866), Macrocyprina decora (Brady, 1866), Macrocyprina maculata (Brady, 1866), Pontocypris attenuata (Brady, 1868), Neocyprideis spinulosa (Brady, 1868), Keijia demissa (Brady 1868), Cytherella semitalis (Brady 1868). Other taxa reviewed and re-illustrated are five species erected by Brady in 1880: Neonesidea woodwardiana, Paranesidea globulus, Loxoconcha pumicosa, Kotaracythere inconspicua, Cletocythereis rastromarginata and Cytherelloidea venusta, and one species described by Brady in 1890: Neomonoceratina entomon. Lectotypes of these have been designated previously, elsewhere. The final species, Neocyprideis timorensis which, although found by Brady in 1880, was first formally described by Fyan in 1916. J. Micropalaeontol. 20(1): 31-44, July 2001.
\end{abstract}

\section{INTRODUCTION}

During the course of studies of Recent shallow-water ostracods from the Solomon Islands, and other localities in the Indo-Pacific, several species were encountered that were, or were comparable with, species originally described by G. S. Brady. There is, however, a degree of confusion surrounding certain of these taxa. Scrutiny of the type material indicates that, in some cases, Brady had included several species under one name. For example, the species recorded as Bairdia crosskeiana by Brady in 1880 from the Challenger Expedition is not the same as that originally described by him in 1866 from the Levant. Likewise, in the Challenger material he included together both Cytheridea spinulosa Brady, 1868 and C. timorensis Fyan, 1916. In addition, there have been several species erected by later workers that can be shown to be junior synonyms, for example, Bishopina mozarti and Aenigmocythere hirudo both proposed by Bonaduce et al. (1976) as the type species of new genera. Similarly, Morkhovenia Teeter, 1975, was based on a single species - Cythere inconspicua Brady, 1880 - but is now known to be a junior synonym of Kotoracythere Ishizaki, 1966. Other taxonomic problems have required resolution, in particular the status of Cletocythereis bradyi Holden, 1967. Brady's original material is, therefore, re-illustrated using SEM and holotypes and lectotypes designated where appropriate.

The original names and revised combinations are as follows: Bairdia crosskeiana Brady, $1866 \quad$ Neonesidea crosskeiana Bairdia woodwardiana Brady, 1880 Neonesidea woodwardiana Bairdia globulus Brady, 1880 Cytherideis (Cytherideis) decora Brady, 1866 Cytherideis (Cytherideis) maculata Brady, 1866 Pontocypris attenuata Brady, 1868 Cytheridea spinulosa Brady, 1868 Cytheridea timorensis Fyan, 1916 Loxoconcha pumicosa Brady, 1880 Cythere demissa Brady, 1866
Cythere inconspicua Brady, 1880

Cytherura entomon Brady, 1890

Cythere rastromarginata Brady, 1880

Cytherella semitalis Brady, 1868

Cytherella venusta Brady, 1880

In the following text, the initials HM indicates that the specimens are housed in the Hancock Museum, Newcastleupon-Tyne. The numbers quoted in McKenzie (1986) were provisional (as already pointed out by Davis \& Horne, 1988) and have now been superseded by those cited herein. The initials BMNH indicates material deposited in The Department of Zoology, The Natural History Museum, London - formerly the British Museum (Natural History).

\section{SYSTEMATIC DESCRIPTIONS \\ Phylum Crustacea Pennant, 1777 \\ Class Ostracoda Latreille, 1806 \\ Order Podocopida Müller, 1894 \\ Suborder Podocopina Sars, 1866 \\ Superfamily Bairdiacea Sars, 1886 \\ Family Bairdiidae Sars, 1888 \\ Subfamily Bairdiinae, Sars 1888 \\ Genus Neonesidea Maddocks, 1969}

Neonesidea crosskeiana (Brady, 1866) (Pl.1, figs 1-3)

1866 Bairdia crosskeiana sp. nov. Brady: 366, pl. 57, fig. 10a-d. 1967 Bairdia crosskeiana Brady; Holden: 12.

1988 Bairdia crosskeiana Brady; Watson MS: pl. 14, figs 21, 22 (lectotype).

non 1880 Bairdia crosskeiana Brady; Brady: 58, pl. 9, fig. 3a-c. non 1890 Bairdia crosskeiana Brady; Brady: 493.

Diagnosis. LV larger, overlapping RV, anteroventral margin broad, obliquely rounded with several short, pointed denticles; posterior acutely pointed at third of height; highly arched dorsal margin, maximum height at anterior third, becoming convex 


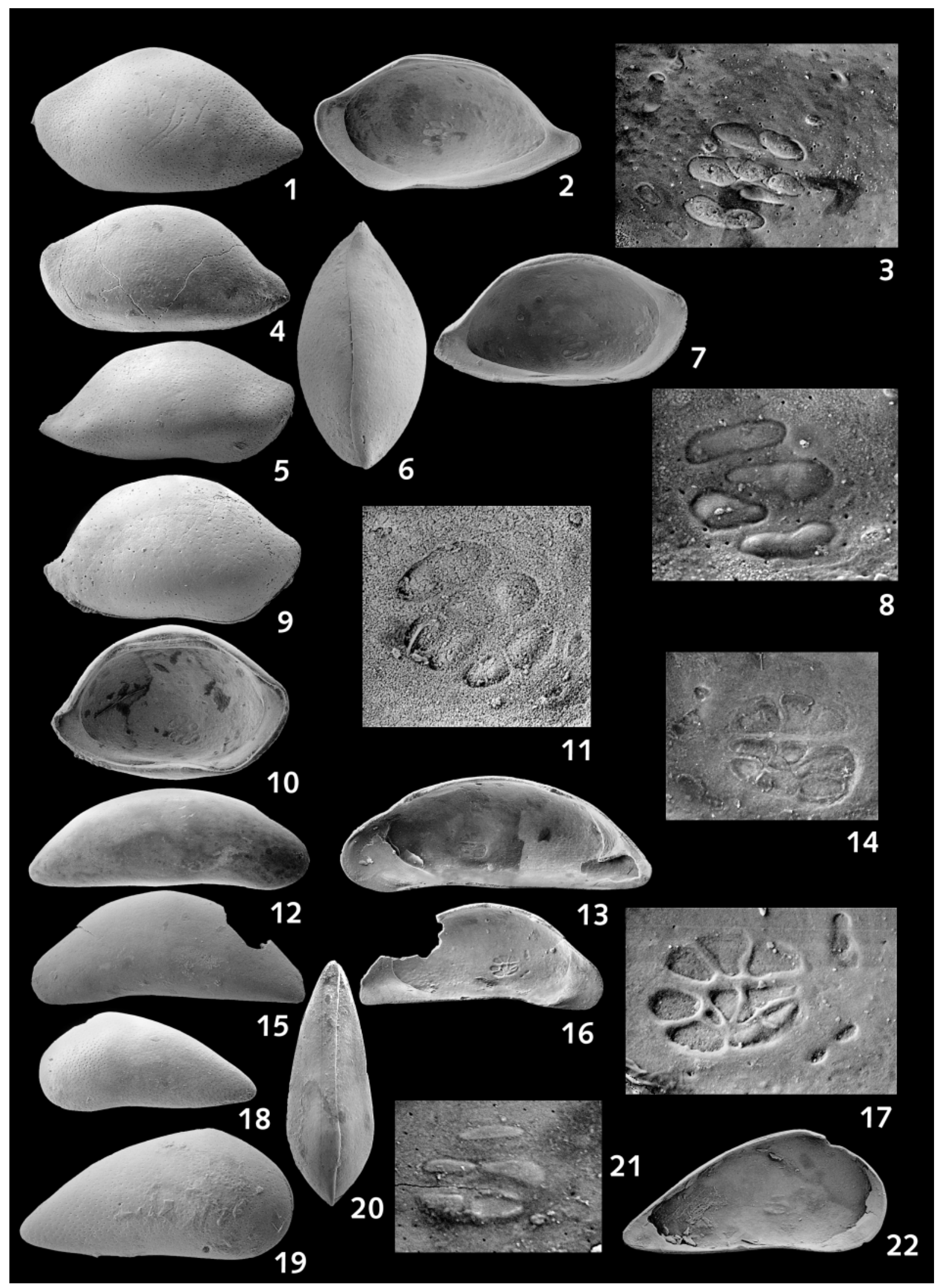


and sloping steeply to posterior with distinct concavity near extremity, anterodorsally very gently concave; ventral margin convex with 8-9 short, pointed denticles posteroventrally. RV typically bairdioid in outline, dorsal margin straight, slightly oblique; anteroventral margin very gently concavo-convex; anterodorsal margin gently concave; posterodorsal margin strongly concave near extremity. Surface finely and densely punctate. Opaque patches, particularly a large, central ovate patch.

Lectotype. LV and RV, HM no. 1.10.43

Material. Brady's original slide HM no. 1.10 .43 contains a left and right adult valve considered to be the disarticulated carapace illustrated by him (pl. 57, fig. 10a-d). HM slide no. 1.09.45 contains syntypic material from the same locality.

Type locality. The Levant, sponge sand. Recent.

Dimensions. Length: lectotype, LV, HM no. 1.10.43, $1.18 \mathrm{~mm}$; lectotype, RV, HM no. 1.10.43, $1.15 \mathrm{~mm}$.

Distribution. A detailed examination of all the specimens included by Brady under the name B. crosskeiana is now needed in order to determine its true distribution. For the moment, it is considered doubtful whether this species occurs in the Pacific Ocean, as recorded by Brady $(1880,1890)$.

Remarks. A lectotype is designated here and illustrated to more properly define this species. There are at least 8 slides labelled Bairdia crosskeiana (with various spellings) in the Brady Collection housed in The Natural History Museum, London (BNHM). These contain a number of species, notably Neonesidea woodwardiana (Brady, 1880) and Neonesidea schulzi sensu lato (Hartmann, 1974). Maddocks (1969, p. 24) noted that Neonesidea schulzi ifalikensis Maddocks, 1969 was possibly the form identified as B. crosskeiana by Brady $(1880,1890)$ from the Pacific; it does not appear to be conspecific with that described by him (Brady, 1866) from the Levant. N. crosskeiana s.s is similar to Neonesidea ritugerda s. $l$. (Holden, 1967) and has the same shape and characteristically humped caudal process. However, Holden's (1967, p. 12) illustration of Bairdia crosskeiana shows a species that is higher and less elongate.

\section{Neonesidea woodwardiana (Brady, 1880)}

$$
\text { (P1.1, figs 4-8) }
$$

1880 Bairdia woodwardiana sp. nov. Brady: 57, pl. 11, fig. 1a-e. 1890 Bairdia woodwardiana Brady; Brady: 494.

1902a Bairdia woodwardiana Brady; Chapman: 230.

1902b Bairdia woodwardiana Brady; Chapman: 421.

1905 Bairdia woodwardiana Brady; Scott: 372.

1910a Bairdia woodwardiana Brady; Chapman: 420.
1915 Bairdia woodwardiana Brady; Chapman: 39.

1976 Bairdia woodwardiana Brady; Puri \& Hulings: 267, pl. 4, figs 16-18 (lectotype).

1988 Bairdia woodwardiana Brady; Watson MS: pl. 20, figs 18-20 (lectotype).

?1995 Paranesidea sp. aff. woodwardiana Brady; Yassini \& Jones: 306, figs 37, 39.

Diagnosis. LV and RV similar, typically bairdioid in shape; RV longer but LV strongly overlapping RV dorsally. Anteroventral margin broad, obliquely rounded; posterior extremely acutely pointed, below ventral $1 / 3$ of height; broadly arched dorsal margin, less so in RV, maximum height at about mid-length, becoming convex antero- and posterodorsally; ventral margin straight in LV, gentle oral concavity in RV. Surface finely and densely punctate. Central muscle scars a patch of 4 discrete, oblong scars.

Lectotype. LV and RV, BMNH no. 80.38.46, designated by Puri \& Hulings (1976).

Material. Brady's original slide is empty. BMNH slide no. 80.38.46 contains a left and right valve (lectotype) and a carapace (paralectotype) and is labelled 'Challenger station no. 172, D18 off Tongatabu'. BMNH slide no. 80.38.28, labelled Bairdia crosskeiana, is also from station 172 and contains 19 specimens of which 4 are $N$. woodwardiana. BMNH slide no. 12.4.51 labelled 'Bairdia crosskeiana, Challenger D16, Narés Harbour, Admiralty Islands', contains one specimen of N. woodwardiana.

Type locality. Off Nukualofa, Tongatabu, southeast of the Fiji Islands, in 18 fathoms, in coral bottom. Recent.

Dimensions. Length: lectotype (disarticulated) - $\mathrm{BMNH}$ no. 80.38.46, LV, $0.94 \mathrm{~mm}$; RV, (same number), $0.95 \mathrm{~mm}$. Paralectotype car, BMNH no. 1988.385, $0.91 \mathrm{~mm}$.

Distribution. Recent, off Tongatabu, Fiji (Brady, 1880, 1890), Funafuti (Chapman, 1902b, 1910a), Cocos Keeling Atoll (Chapman, 1902b), east of Tasmania (Chapman, 1915), Sri Lanka (Scott, 1905) and possibly off Australia (Yassini \& Jones, 1995). Unless the last-named record is of the species, there has been no published figure since the original description, apart from the re-illustration of the lectotype by Puri \& Hulings (1976).

Remarks. Neonesidea? sp. aff. N. woodwardiana of Williams (1980 MS), Titterton (1984 MS) and Titterton \& Whatley (1988) recorded in the Quaternary and Recent of the Solomon Islands are shown to be a separate species by Watson (1988) MS and differ most markedly in possessing a very elaborate muscle scar pattern.

\section{Explanation of Plate}

Figs 1-3. Neonesidea crosskeiana (Brady, 1866): 1, lectotype (Hancock Museum no. 1.10.43), LV external view; 2, 3, lectotype (Hancock Museum no. 1.10.43), RV internal view, and details of muscle scars, respectively; 1, 2, $\times 40, \mathbf{3}, \times 150$. From the Levant, sponge sand. Figs $\mathbf{4 - 8}$. Neonesidea woodwardiana (Brady, 1880): 4, 7, 8, lectotype (BMNH no. 80.38.46), LV external, internal views, and details of muscle scars, respectively; 5, lectotype (BMNH no. 80.38.46), RV external view; 6, paralectotype (BMNH no. 1988.385, ex slide 80.38.46), carapace, dorsal view; 4, 5, 7, $\times 45$, 6, $\times 47,8, \times 240$. From off Nukualofa, Tongatabu, Challenger station 172, SW Pacific. Figs 9-11, Paranesidea globula (Brady, 1880): 9, lectotype (BMNH no. 80.38.34), RV external view; 10, 11, lectotype (BMNH no. 80.38.34), LV external view and details of muscle scars, respectively; 9, $\times 43$; 10, $\times 40 ; 11, \times 190$. From Narés Harbour, Admiralty Islands, W. Pacific. Figs 12-14, Macrocyprina decora (Brady, 1866): lectotype (Hancock Museum no. 1.12.37), RV external, internal views and details of muscle scars, respectively; 12, $\times 40,13, \times 44,14, \times 200$. From off Australia. Figs 15-17, Macrocyprina maculata (Brady, 1866): lectotype (Hancock Museum no. 2.06.42), LV external, internal views, and details of muscle scars, respectively; 15, $\times 48, \mathbf{1 6}, \times 43, \mathbf{1 7}, \times 220$. From slide labelled 'Australia, West Indies'. Figs 18-22. Pontocypris attenuata Brady, 1868: 18, 21, 22, paralectotype (Hancock Museum no. 1.58.33, ex slide, 1.04.09), LV external view, details of muscle scars, and LV internal view, respectively; 19, 20, lectotype (Hancock Museum no. 1.58.32, ex slide 1.04.09), carapace, external view of RV, and dorsal view, respectively; 18, $\times 58, \mathbf{1 9}, \times 72, \mathbf{2 0}, \times 65$, 21, $\times 330,22, \times 70$. From Mauritius. 
Genus Paranesidea Maddocks, 1969

Paranesidea globulus (Brady, 1880)

(P1.1, figs 9-11)

1880 Bairdia globulus sp. nov. Brady: 54, pl.9, fig. 1a-d. 1976 Bairdia globulus Brady; Puri \& Hulings: pl. 4, figs 6-11 (lectotype).

1988 Bairdia globulus Brady; Watson MS: pl. 16, figs 7, 8 (lectotype).

Diagnosis. Carapace tumid, sub-circular in shape in lateral view; broadly ovate in dorsal view. LV larger, strongly overlapping RV along periphery. Anterior very broadly rounded, extremity at mid-height, narrow flange anteroventrally; posterior bluntly caudate in LV, slightly more cavolate in RV, extremity at $1 / 3$ of height. LV tumid ventrolaterally, overhanging ventral margin so ventral margin appears convex in lateral view. Valve surface with fine, sparse puncta. Large central opaque patch observed in LV, shaped like an amphora.

Lectotype. LV and RV, BMNH no. 80.38.34, designated by Puri \& Hulings (1976).

Material. Brady's original slide is empty. BMNH slide no. 80.38.34 contains a left and right valve (lectotype) and is labelled 'Challenger D16, Narés Harbour, Admiralty Islands, March 2 1875'. A second slide from the same locality contains 2 juveniles, only 1 of which is $P$. globulus.

Type locality. Dredging at 16-25 fathoms, Narés Harbour, Admirality Islands, north of New Guinea. Recent.

Dimensions. Length: lectotype (disarticulated) - BMNH no. 80.38.34, LV, $1.05 \mathrm{~mm}$; RV (same number), $1.04 \mathrm{~mm}$.

Distribution. Only known from the type locality.

Remarks. Paranesidea? globulus and P? paucipunctata of Titterton \& Whatley (1988); P? confusa Titterton \& Whatley, 1988; ?Neonesidea tigra Watson, $1988 \mathrm{MS}$; and Bairdia gigacantha Kornicker, 1961 are all very similar and form a morphological group, possibly a new genus, with affinities to both Paranesidea and Neonesidea (K. A. Watson, 1988, pers. comm.). Differences in shape, particularly dorsally and posteriorly distinguish the species within the group, as well as differences in details of the muscle scars and opaque patches. For example, in the left valve, $P$ ? confusa possesses 2 conspicuous patches either side of a large sub-central stripe; in $P$ ? paucipunctata the large sub-central patch is skittle-shaped, ?N. tigra possesses a broad central 'stripe', whereas in the present species this patch is shaped more like an amphora.

Superfamily Cypridacea Baird, 1845

Family Macrocyprididae Müller, 1912

Genus Macrocyprina Triebel, 1960

Macrocyprina decora (Brady, 1866)

(P1. 1, figs 12-14)

1866 Cytherideis (Cytherideis) decora sp. nov. Brady: 366, pl. 57, fig. $13 \mathrm{a}-\mathrm{c}$.

1868 Paracypris hieroglyphica sp. nov. Brady: 62, pl. 7, figs 7, 8. 1880 Macrocypris decora (Brady); Brady: 44, pl.1, fig. 3a-d, pl. 6, fig. $8 \mathrm{a}-\mathrm{b}$.

1952 Macrocypris decora (Brady); Hornibrook: 13, 16, 17.

1977 Macrocyprina decora (Brady); Maddocks: 148.

1978 Macrocypris decora (Brady); De Deckker \& Jones: 132. 1983 Macrocypris decora (Brady): Gou, Zheng \& Huang.: 16, pl. 2, figs 18-21.
1985 Macrocypris decora (Brady); Wang \& Zhao: 75, pl. 6, fig. 6. 1987 Macrocypris sp. aff. M. decora (Brady); Whatley \& Zhao: 336 , pl. 11, figs $27,28$.

1990 Macrocyprina decora (Brady); Maddocks: 114 [nomen dubium].

1997 Macrocypris decora (Brady); Dewi: 57, fig. 28.

Diagnosis. Elongate, sub-elliptical in shape in lateral and dorsal views. Dorsal margin broadly and evenly arched, maximum height central; very slight concavity anterodorsally. Ventral margin slightly arcuate; posterior extremity subventral, narrow, rounded. Inner lamella very wide anteriorally, broadly concave. Valve smooth. Opaque.

Holotype. RV, HM no. 1.12.37.

Material. There is only one specimen, a RV as illustrated by Brady (1866) taken from slide HM no. 1.12.37, labelled Cytherideis decora. A second slide, HM no. 2.06.42, labelled 'Cytherideis maculata, Cytherideis decora Australia, West Indies', only contains a left valve of C. maculata.

Type locality. Australia, 17 fathoms. Recent.

Dimensions. Length: holotype RV, HM no. 1.12.37, $1.22 \mathrm{~mm}$.

Distribution. Wide distribution in the Recent around Australia, New Zealand, Indonesia, East China Sea, Pacific Ocean and Indian Ocean and South Atlantic Ocean. Miocene and Pliocene of India, Australia and China.

Remarks. The species is placed in Macrocyprina, rather than Macrocypris, following Maddocks (1990).

Brady (1866) described a right valve of $M$. decora as elongate triangular in shape and $1.05 \mathrm{~mm}$ in length. In the same paper he also described a larger left valve, of $M$. maculata, as oblong, arcuate, compressed and $1.16 \mathrm{~mm}$ in length. There are only two specimens in the Brady Collection that can be referable to these two species: a right valve which is more elongate and compressed and is longer $(1.22 \mathrm{~mm})$ and a left valve which is more triangular in shape and smaller $(0.99 \mathrm{~mm})$. Despite these discrepancies, confirmation that the left valve is indeed $M$. maculata is provided by the fact that it possesses opaque patches as described by Brady, whereas $M$. decora is opaque (all over). Our evidence notwithstanding, Maddocks (1990, p. 114) argues that the status of the species is best left as a nomen dubium. However, we believe that she may not have seen slide HM no. 1.12.37 and that, if she had, her interpretation of the status of this species may have been different.

\section{Macrocyprina maculata (Brady, 1866)}

(P1. 1, figs 15-17)

1866 Cytherideis (Cytherideis) maculata sp. nov. Brady: 367, pl.57, fig. $12 \mathrm{a}-\mathrm{b}$.

?1880 Macrocypris maculata (Brady): Brady: 44, pl. 1, fig. 2a-d. 1977 Macrocyprina maculata (Brady); Maddocks: 148.

1980 Macrocypris sp. 1 Williams MS: 47, pl. 2, figs 9, 10.

1984 Macrocypris sp. aff. M. decora Titterton MS: 135, pl. 4, figs 8 , 10; pl. 27, fig. 2 .

1988 Macrocyprina maculata (Brady); Watson MS: 85, pl. 19, figs $1-5$.

1990 Macrocyprina maculata (Brady); Maddocks: 119 [nomen dubium].

Diagnosis. Elongate, arcuate, subtriangular in lateral view. Anterior margin very narrow, directed downwards; dorsal margin strongly and evenly arched, maximum height central; 
ventral margin broadly concave. Inner lamella wide, broad anterior and posterior vestibulae. Valve smooth, translucent with three opaque patches, one sub-central, two large patches at anterior and posterior.

Holotype. LV, HM no. 2.06.42

Material. HM slide no. 2.06.42 is labelled 'Cytherideis maculata, Cytherideis decora. Australia, West Indies', but only contains a left valve of C. maculata as illustrated by Brady (1866).

Type locality. Not designated. Recent.

Dimensions. Length: holotype LV, no. HM 2.06.42, $0.99 \mathrm{~mm}$.

Distribution. Brady (1880) recorded this species from depths of 15-150 fathoms from Simon's Bay, South Africa; Kerguelen Island and Prince Edward Is., southern Indian Ocean; off East Mancoer Island, Bass Strait and off Amboyna in the South China Sea. It is doubtful whether the same species was recorded at all these stations (Watson, 1988 MS, pers.comm.). Brady originally recorded the species from Western Australia, the West Indies (Turks Island). It also occurs in Quaternary (Williams, 1980 MS) and Recent (Titterton, 1984 MS) sediments from the Solomon Islands and around Pulau Seribu, in the Java Sea (Watson, 1988 MS).

Remarks. In spite of the size discrepancy and Maddocks' (1990) misgivings, the distinctive opaque-patch pattern of our figured specimen suggests that it is indeed Brady's holotype. For further comments on this species, see Remarks under $M$. decora, above.

Family Pontocyprididae Müller, 1894

Genus Pontocypris Sars, 1866

Pontocypris attenuata Brady, 1868

(Pl. 1, figs 18-22)

1868 Pontocypris attenuata sp. nov. Brady: 179, pl. 4, figs 11-14. 1880 Pontocypris attenuata Brady; Brady: 38, pl. 15, fig. 2a-d. 1902b Pontocypris attenuata Brady; Chapman: 419. 1910a Pontocypris attenuata Brady; Chapman: 427. 1910b Pontocypris attenuata Brady; Chapman: 298. ?1915 Pontocypris attenuata Brady; Chapman: 34, pl. 2, fig. 1. 1928 Pontocypris attenuata Brady; Chapman \& Crespin: 169. 1963 Pontocypris attenuata Brady; Ishizaki: 22, pl. 2, fig. 2. 1968 Pontocypris attenuata Brady; Ishizaki: 16, pl. 3, fig. 6. 1992 Pontocypris cf. Pontocypris attenuata (Brady); Mostafawi: p. 136, pl. 8, fig. 177.

1997 Pontocypris cf. P. attenuata (Brady); Dewi: 58, figs 40-42. non 1890 Pontocypris attenuata Brady; Brady: 491, pl. 1, figs 3-4. non 1919 Pontocypris attenuata Brady; Chapman: 17.

non 1941 Pontocypris attenuata Brady; Chapman: 194, pl. 9, fig. 8.

Diagnosis. Elongate, subtriangular in shape in lateral view, narrow kite-shape in dorsal view, widest at anterior third. Anterior margin broadly rounded, posterior acuminate, sharply pointed, extremity ventral. Dorsal margin angularly arched, maximum height and angle at anterior third; ventral margin gently biconvex. Surface of valve minutely punctate; translucent with opaque patches; a large subcentral patch and a smaller posteromedian patch.

Lectotype. ? $\odot$ car., HM no. 1.58 .32 (ex slide no. 1.04.09).

Material. The original HM slide no. 1.04.09 contained ten specimens.
Type locality. Mauritius, Indian Ocean. Recent, in mud.

Dimensions. Length: lectotype ?+car., HM no. 1.58.32, $0.66 \mathrm{~mm}$; paralectotype LV, HM no. $1.58 .38,0.65 \mathrm{~mm}$.

Distribution. Pontocypris attenuata occurs widely in shallowwater assemblages of the Indo-Pacific, from Mauritius in the west to Japan in the north and off southeastern Australia, Funafuti and the Solomon Islands. BMNH slide no. 80.38.6, Hong Kong Harbour, 7 fathoms (Brady, 1880) contains some juveniles and BMNH slide no. 12.4.64, Humbolt Bay, Papua, 37 fathoms, contains adults of this species. In the fossil, it is recorded in the Batesford Limestone (Chapman, 1910b), the Tertiary of the Sorento Bore, Victoria, Australia (Chapman \& Crespin, 1928) and Miocene of the Yatsuo Formation, Japan (Ishizaki, 1963).

Remarks. Maddocks, in her review of the Pontocyprididae (1991, table 1, p. 311) seems to include this species in Propontocypris Sylvester-Bradley, 1947. She then lists (1991, p. 328) among the species included within Propontocypris by original binomen - 'Propontocypris (Propontocypris) attenuata (Brady, 1868) of Okubo (1979)'. However, since she does not seem to mention Pontocypris attenuata Brady, 1868 elsewhere, it is possible that she may have overlooked this species in her review.

\section{Superfamily Cytheracea Baird, 1850 \\ Family Cytheridea Baird, 1850}

Genus Neocyprideis Apostolescu, 1956

1957 Goelichia Keij: 69.

1960 Miocyprideis Kollmann: 176.

1976 Bishopina Bonaduce, Masoli \& Pugliese: 397.

Remarks. Neocyprideis is very closely related to Cyprideis Jones, 1857 , but differs mainly in the structure of the hinge which, in Cyprideis, is pseudoentomodont. Kollmann (1960) erected Miocyprideis which differed from Neocyprideis in possessing anterior and posterior marginal denticles, more numerous marginal pore canals and a very strong ventral overlap of the left valve over the right valve. The present authors agree with Van Morkhoven (1963, p. 295) that these differences are insufficient to allow Miocyprideis generic status. The diagnosis of Neocyprideis, therefore, should be expanded to accommodate those species assigned to Miocyprideis and the stratigraphical range of the genus extended to the Recent. Babinot \& Colin (1976) would disagree and would contend that the shape of the carapace and hinge are important features in separating Miocyprideis from Neocyprideis. We would argue, however, that the degree of variation in these two characters alone in the species they would place in their two separate genera is enough to demonstrate that this is just one group of species. Babinot $\&$ Colin (1976), in their interesting paper on the evolution of the Cytherideinae, also follow in essence the scheme of evolution of Kollmann (1960) from Fabanella via their genus Sarlatina to Cyprideis, with another branch evolving from Fabanella to Neocyprideis and Miocyprideis. However, we regard this phylogeny as too simplistic and regard Neocyprideis as a sibling (or even possible ancestral) genus of Cyprideis.

Bonaduce et al. (1976) established the genus Bishopina which is small and is distinguished by a modified marginal area, an amphidont hinge of which the left valve comprises an elongate 


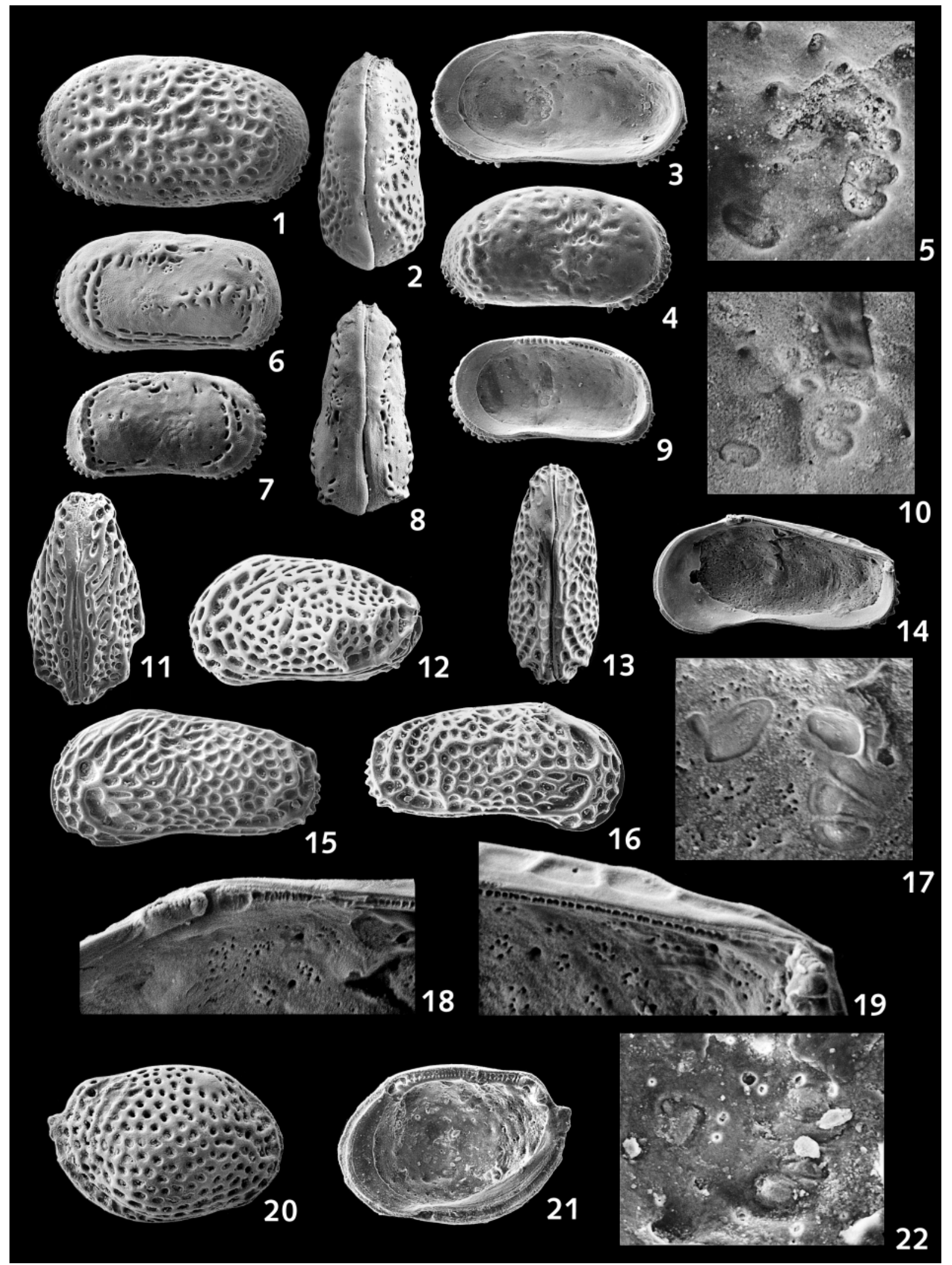


anterior loculate socket, a denticulate median element with 9 toothlets, compared to about 20 in Miocyprideis (see Malz \& Ikeya, 1986), and a short posterior loculate socket; a muscle scar pattern of a vertical row of 4 adductor scars with 2 anterior antennal scars, a fulcral point and 2 smaller anteroventral scars. These features are not considered to be sufficient to distinguish Bishopina from Neocyprideis. The former has, therefore, been placed in the synonymy of Neocyprideis.

\section{Neocyprideis spinulosa (Brady, 1868)}

(P1. 2, figs 1-5)

1868 Cytheridea spinulosa sp. nov. Brady: 182, pl. 13, figs 1-6. 1880 Cytheridea spinulosa Brady; Brady: 112, pl. 33, fig. 6a-d. 1890 Cytheridea spinulosa Brady; Brady: 505.

1916 Cytheridea spinulosa Brady; Fyan: 1210, figs 7, 8.

1954 Clithrocytheridea spinulosa (Brady); Keij: 352, pl. 1, fig. 2. 1960 Miocyprideis spinulosa (Brady); Kollmann: 178, pl. 18, figs 12 , 13; pl. 19, fig. 16 .

1963 Miocyprideis spinulosa (Brady); Van Morkhoven: 296.

1968 Clithrocytheridea spinulosa (Brady); Guha: 212.

1981 Bishopina spinulosa (Brady); Wouters: 5.

1986 Miocyprideis spinulosa; Malz \& Ikeya: 178, pl. 2, figs 1-9; pl. 3, fig. 10.

1986 Clithrocytheridea cf. spinulosa (Brady); Cabioch, Anglada \& Babinot: 26, pl. 8, figs 12-14.

1988 Neocyprideis spinulosa (Brady); Watson MS: 108, pl. 22, figs $1-9$.

1989 Neocyprideis spinulosa (Brady); Whatley \& Keeler: pl.1, figs $6,9-11,13$.

1989b Miocyprideis spinulosa (Brady); Zhao \& Whatley: 235, pl. 1, figs 12-14.

1989 Bishopina spinulosa (Brady); Howe \& McKenzie: 16, figs $62,63$.

1993 Miocyprideis spinulosa (Brady); Jellinek: 123, fig. 207.

1995 Miocyprideis spinulosa (Brady). Babinot \& Kouyoumontzakis: 30, pl. 2, figs 17-19.

1998 Miocyprideis spinulosa (Brady); Hussein: 7, pl. 2, fig. 3.

Diagnosis. Medium in size, thick shelled. Subrectangular in shape in lateral and dorsal views; greatest height just posterior of mid-length; greatest width posteriorly. Surface of valves coarsely punctate, punctae large, deep, irregular subcentrally; becoming finely punctate around periphery.

Lectotype. + car., HM no. 1.58 .39 (ex slide no. 1.47.10).

Material. The original HM slide no. 1.47.10, labelled Cytheridea spinulosa from Mauritius, contained 38 specimens but only 7 are $N$. spinulosa, the other 31 are $N$. timorensis (Fyan, 1916), several of which have been illustrated for comparison in Plate 2, figs 6-10. BMNH slide no. 80.38.124, from Amboyna, 15-20 fathoms of Brady (1880) contains $N$. spinulosa.

Type locality. Mauritius, Indian Ocean. Recent, in mud.

Dimensions. Length: lectotype + car., HM no. 1.58.39, $0.65 \mathrm{~mm}$; paralectotype § RV, HM no. 1.58.38, $0.61 \mathrm{~mm}$.

Distribution. Neocyprideis spinulosa is one of the most widely distributed shallow-water species of the present day, occurring in the subtropical belt from as far west as the eastern coast of South Africa, across Indonesia to the Solomon Islands in the east. The earliest fossil occurrence of this species is from the Upper Pliocene sediments of Timor (Fyan, 1916). Other fossil records include the Pliocene-Pleistocene of Southern India (Guha, 1968) and the Quaternary of the Solomon Islands (Williams, 1980, MS) and Fijian Islands (Malz \& Ikeya, 1986). Remarks. Neocyprideis spinulosa differs from $N$. timorensis (Fyan, 1916) in that the punctate/reticulate ornament extends across the entire lateral surface and is coarsest and most irregular centrally; it is also consistently and conspicuously larger in size than the latter. The punctate ornament is variable, even within a single population, for example the specimens in Brady's original slide all vary. Some populations are particularly heavily ornamented, such as those described by Cabioch et al. (1986).

Neocyprideis timorensis (Fyan, 1916)

(P1. 2, figs 6-10)

1916 Cytheridea timorensis sp. nov. Fyan: 1211, fig. 9. 1976 Bishopina mozarti sp. nov. Bonaduce, Masoli \& Pugliese: 397, pl. 12, figs 1-7.

1977 Cytherelloidea sp. Hughes MS: pl. 70, fig. 10.

1980 Neocyprideis timorensis (Fyan), Williams MS: 57, pl. 3, figs 6-8.

1986 Bishopina timorensis (Fyan), Malz \& Ikeya, pl. 3, figs $1-3$.

1988 Neocyprideis timorensis (Fyan), Watson MS: 110, pl. 22, figs $10-18$.

1988 Neocyprideis timorensis (Fyan), Taylor MS: 42, pl. 2, figs $22,23$.

non 1984 Neocyprideis timorensis (Fyan), Titterton MS: 197, pl. 7, figs 1-2; pl. 31, figs 6-16.

Dimensions. Length: + car. HM no. $1.58 .41,0.55 \mathrm{~mm}$; ô car. HM no. $1.58 .40,0.51 \mathrm{~mm}$.

Distribution. The Recent of the Red Sea, Singapore, West Malay Peninsula, Java Sea, the Upper Pliocene of Timor and Miocene to Quaternary of the Solomon Islands.

Explanation of Plate 2

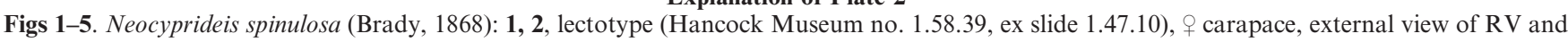
dorsal view, respectively; 3-5, paralectotype (Hancock Museum no. 1.58.38, ex slide 1.47.10), ô RV internal, external views and details of muscle scars, respectively; 1, 3, $\times 68, \mathbf{2}, \times 54, \mathbf{4}, \times 60, \mathbf{5}, \times 400$. From Mauritius. Figs 6-10. Neocyprideis timorensis (Fyan, 1916): 6, 8 (Hancock Museum no. 1.58.41, ex slide 1.47.10), क carapace, external view of RV and dorsal view, respectively; 7, 9, 10 (Hancock Museum no. 1.58.40, ex slide 1.47.10), $\widehat{~ R V ~ e x t e r n a l ~ a n d ~ i n t e r n a l ~ v i e w s ~ a n d ~ d e t a i l s ~ o f ~ m u s c l e ~ s c a r s, ~ r e s p e c t i v e l y ; ~ 6, ~ 9, ~} \times 65, \mathbf{7}, \mathbf{8}, \times 60, \mathbf{1 0}, \times 365$. From Mauritius. Figs 11, 12 . Kotoracythere inconspicua (Brady, 1880): lectotype (BMNH no.81.5.22), carapace, dorsal view and external view of LV, respectively; 11, $\times 87, \mathbf{1 2}$, $\times$ 95. From Torres Strait, Challenger station 185, W. Pacific. Figs 13-19. Keijia demissa (Brady, 1868): 13, 15, lectotype (Hancock Museum no. 1.58.34, ex slide 2.05.39), ô carapace, dorsal and external view of LV, respectively; 14, 16-19, paralectotype (Hancock Museum no. 1.58.35, ex slide no 2.05.39), \& RV internal and external views, details of muscle scars and anterior and posterior parts of hinge, respectively; 13, $\times 80, \mathbf{1 4}, \times 85, \mathbf{1 5}$, $\times 100, \mathbf{1 6}, \times 90, \mathbf{1 7}, \times 510, \mathbf{1 8}, \mathbf{1 9}, \times 390$. From Mauritius. Figs 20-22. Loxoconcha pumicosa Brady, 1880: Lectotype (BMNH no. 81.5.37), RV external and internal views, and details of muscle scars, respectively; 20, 21, $\times 78, \mathbf{2 2}, \times 390$. From Narés Harbour, Admiralty Islands, W. Pacific. 
Remarks. The figured specimens are taken from the original HM slide no. 1.47.10, labelled 'Cytheridae spinulosa, Mauritius' in which there are 38 specimens, 31 of which are $N$. timorensis, later described by Fyan (1916). This species is illustrated for comparison with $N$. spinulosa as the two species are often found in association, for example in Fyan (1916), Brady (1868) and in the Solomon Island fauna, known to us, both Quaternary and Recent.

Family Loxoconchidae Sars, 1925

Subfamily Loxoconchinae Sars, 1925

Genus Loxoconcha Sars, 1866

Loxoconcha pumicosa Brady, 1880

(P1. 2, figs 20-22)

1880 Loxoconcha pumicosa sp. nov. Brady: 118, pl. 28, fig. 2a-d. 1890 Loxoconcha pumicosa Brady; Brady: 507.

1976 Loxoconcha pumicosa Brady; Puri \& Hulings: 298, pl. 18, figs 10-12 (lectotype).

1984 Loxoconcha sp. cf. L. pumicosa Brady; Titterton MS: 362, pl. 11, figs 7-8; pl. 46, figs 11-21.

1988 Loxoconcha pumicosa Brady; Watson MS: 181, pl. 34, figs $7-16$.

Diagnosis. A species of Loxoconcha with an ornament of closely and concentrically arranged, subcircular, deep punctae aligned longitudinally ventrally. Sub-rhomboidal in shape in lateral view, elliptical in dorsal view, greatest width median. Posterior margin with blunt, upturned caudal process, well above midheight; dorsal margin gently arched with gentle concavity behind posterior cardinal angle.

Lectotype. + RV, BMNH no. 81.5.37, designated by Puri \& Hulings (1976).

Material. BMNH slide no. 81.5.37 contains only one right valve. Puri \& Hulings state that this was a carapace and that there is another carapace as well. This and the left valve (if they had split the valves) were not found.

Type locality. Narés Harbour, Admiralty Islands, just north east of New Guinea, 16 fathoms, collected March, 1875. Recent.

Dimensions. Length: lectotype $\odot$ RV, BMNH no. 81.5.37, $0.48 \mathrm{~mm}$.

Distribution. Recorded by Brady (1880) from the Recent of Booby Island and the Admirality Islands and (1890) from New Caledonia, Fiji and Samoa. It also occurs in the Recent around Pulau Seribu, Java Sea (Watson, 1988 MS) and the Solomon Islands (Titterton 1984 MS).

\section{Family Pectocytheridea Hanai, 1957 Genus Keijia Teeter, 1975}

Keijia demissa (Brady, 1868)

(Pl. 2, figs 13-19)

1868 Cythere demissa sp. nov. Brady: 180, pl. 12, figs 1, 2. 1890 Cythere demissa Brady; Brady: 497.

1953 Leptocythere demissa (Brady); Hornibrook: 13, 17, 21. 1973 Leptocythere demissa (Brady); Teeter: 47, fig. 2a-g.

1975 Keijia demissa (Brady); Teeter: 436, figs 7r, s, 8e. 1976 Aenigmocythere hirundo sp.nov. Bonaduce, Masoli \& Pugliese: 380 , pl. 4, figs 6-11, text-fig. 4.

1978 Pectocythere? foveata sp. nov. Hartmann: 144, pl. 14, figs 12, 13; text-figs 619, 620 .
1980 Hemicytheridea anterocostata sp. nov. Williams MS: 88, pl. 5, figs 2-4, 6 [nomen nudum].

1984 Hemicytheridea anterocostata sp. nov. Titterton MS: 415, pl. 14, figs 5, 6; pl. 51, figs 1-10 [nomen nudum].

?1985 Keijia novilunaris sp. nov. Zhao; Zhao, Wang \& Zhang: 211, pl. 21, figs 14-18.

1986 Keijia demissa (Brady); Cabioch, Anglada \& Babinot: 25, pl. 8, figs 4, 5 .

1987 Keijia demissa (Brady); Whatley \& Zhao: 353, pl. 5, figs 27, 28.

1987 Pectocythere foveata Hartmann; Yassini \& Jones: 826, pl. 14, figs $12,13$.

1988 Keijia demissa (Brady); Taylor MS: 90, pl. 6, figs 10, 11. 1988 Keijia demissa (Brady); Watson MS: 211, pl. 40, figs 15-26. 1989a Keijia demissa (Brady); Zhao \& Whatley: 171.

1989 Keijia demissa (Brady); Whatley \& Keeler: 73, pl. 4, figs 12-14.

1989 Pectocythere (?) foveata Hartmann; Howe \& McKenzie: 32. 1989 Mckenziartia foveata (Hartmann); Yassini \& Mikulandra: 133, figs $2 \mathrm{~g}-\mathrm{i}, 3 \mathrm{~g}, 4 \mathrm{~b}$.

1991 Keijia hirundo (Bonaduce, Masoli \& Pugliese); Behrens: 113, pl. 2, figs 12, 13 .

1991 Keijia foveata (Hartmann); Behrens: 114, pl. 3, figs 1, 2. 1992 Keijia borneoensis sp. nov. Mostafawi: 140, pl. 2, figs $41-43$.

1992 Keijia demissa (Brady); Mostafawi, pl. 2, fig. 44 (lectotype). 1993 Keijia demissa (Brady); Witte: 26, pl. 4, figs 10-12.

1995 Keijia demissa (Brady); Babinot \& Kouyoumontzakis: 20, pl. 1, figs 20, 21.

1995 Keijia demissa (Brady); Yassini \& Jones: 338, figs 271-274. 1995 Keijia demissa (Brady); Shyam Sunder, Varma \& Naidu: 473, 476, 478, pl. 1, figs 7, 8 .

1998 Keijia demissa (Brady); Hussein: 6, pl. 1, fig. 16.

non 1880 Cythere demissa Brady. Brady; 66, pl. 12, fig. 7a-h. non 1954 Leptocythere demissa (Brady); Keij: 354, pl. 1, fig. $3 \mathrm{a}, \mathrm{b}$.

Diagnosis. A species of Keijia, elongate, narrowly subrectangular in shape in lateral and dorsal views. Strongly reticulate with the peripheral muri concentric to the margins being strengthened into ribs, dominated by a strong anterior submarginal rib behind which are two large drop-shaped fossae. Three prominent posterior ribs, one peripheral around the posterior, continuing ventrally and submarginally to merge into the anterior rib; the second is short, the third links with the ventral submarginal rib.

Lectotype. of car., HM no. 1.58 .34 (ex slide no. 2.05.39) (this has already been illustrated by Mostafawi, 1992, pl. 2, fig. 44).

Material. The original HM slide no. 2.05.39, labelled 'Cythere demissa, Cythere convoluta, Cythere perplexa' contains 7 specimens, 4 of which are $C$. demissa; the other 3 are neither $C$. convoluta nor $C$. perplexa.

Type locality. Mauritius, about 450 miles east of Madagascar, Indian Ocean. Recent in mud.

Dimensions. Length: lectotype ô car., HM no. 1.58.34, $0.44 \mathrm{~mm}$; paralectotype $q$ RV, HM no. 1.58.35, $0.46 \mathrm{~mm}$.

Distribution. Widely distributed across the Indo-Pacific and Australia and believed to have been transported by passive dispersal by ships (Witte, 1993) into the Caribbean and Atlantic, although the present authors doubt this. Full details of its distribution are given by Witte (1993, p. 27). Also found in the 
Quaternary of the Solomon Islands (Williams MS, 1980) and New Caledonia (Cabioch et al., 1986).

Remarks. Behrens (1991, pls 2, 3) illustrates the female of this species as Keijia hirundo (Bonaduce, Masoli \& Pugliese, 1976) and the male as Keijia foveata (Hartmann, 1978). Moreover, we consider K. borneoensis Mostafawi (1992) to be nothing more than an ornamental variant of $K$. demissa.

Genus Kotoracythere Ishizaki, 1966

Kotoracythere inconspicua (Brady, 1880)

(Pl. 2, figs 11, 12)

1880 Cythere inconspicua sp. nov. Brady: 70, pl. 13, fig. 1a-d. 1890 Cythere cuneolus sp. nov. Brady: 500, pl. 2, figs 6, 7. 1954 Leptocythere inconspicua (Brady); Keij: 354, pl. 1, fig. 4. 1968 Leptocythere inconspicua (Brady); Guha: 60, pl. 4, fig. 10. 1973 Leptocythere inconspicua (Brady); Teeter: 47, fig. $1 \mathrm{~g}-1$. 1975 Morkhovenia inconspicua (Brady); Teeter: 435, figs 7o-q, 8c 1976 Munseyella inconspicua (Brady); Holden: 34, pl. 1, figs $14-16$, pl. 11, figs 3-5.

1976 Cythere inconspicua Brady; Puri \& Hulings: 278, pl. 6, figs 10-12 (lectotype).

1980 Pectocythere sp. ceduna 120 Hartmann: 123, pl. 3, figs 14-17. 1980 Kotaracythere cf. inconspicua (Brady); Williams MS: 90, pl. 15, fig. 5 .

1981 Morkhovenia cf. inconspicua (Brady); Hartmann: 120, pl. 10, figs 1-6, text- figs 58-61b.

1981 Kotoracythere inconspicua (Brady); Keeler MS: 155, pl. 9, figs 5-7.

1984 Kotoracythere inconspicua (Brady); Titterton MS: 430, pl. 14, figs 8, 9; pl. 50, figs 11-20.

1986 Morkhovenia cuneola (Brady) (sic): McKenzie: pl. 2, fig. 8 (lectotype).

1986 Morkhovenia inconspicua (Brady). Cabioch, Anglada \& Babinot: 25, pl. 8, fig. 3.

1988 Kotoracythere inconspicua (Brady); Watson MS: 214, pl. 41, figs 1-10.

1989a Kotoracythere inconspicua (Brady); Zhao \& Whatley: 186. 1989 Kotoracythere inconspicua (Brady); Whatley \& Keeler: 76, pl. 3, fig. 11; pl. 5, figs 6-7.

1990 Morkhovenia kingstoni sp. nov. McKenzie, Reyment \& Reyment: 11, pl. 3, fig. 1.

1991 Kotoracythere inconspicua (Brady); Witte \& Van Harten: 434, figs 3a-n, 4a-x, 5a-v.

1991 Morkhovenia inconspicua (Brady); Behrens: 113, pl. 4, figs $9,10$.

1993 Kotoracythere inconspicua (Brady); Witte: 25, pl. 3, figs 19-22.

1995 Kotoracythere inconspicua (Brady); Babinot \& Kouyoumontzakis: 28, pl. 1, figs 12, 13.

1995 Kotoracythere inconspicua (Brady); Yassini \& Jones: 338, figs 287, 288.

1996 Kotoracythere inconspicua (Brady); Babinot \& DegaugueMichalski: 361.

Diagnosis. A species of Kotoracythere with valves deeply and strongly reticulate; fossae irregular in shape, larger and elongate peripherally centric to margins; smaller, more ovate on posteroventral and posteromedian inflation of valves. Subrectangular in shape in lateral view; hastate in dorsal view. Anterior broadly rounded; posterior narrow, truncated.
Lectotype. ô car, BMNH no. 81.5.22, designated by Puri \& Hulings (1976).

Material. BMNH slide no. 81.5.22, labelled 'Cythere inconspicua, Challenger station 185, depth 155 fathoms' contains 1 carapace. Puri \& Hulings state there should also be a damaged left valve.

Type locality. Torres Strait, between Northeastern Australia and southern New Guinea, dredging at 155 fathoms. Recent, from sand. Dimensions. Length: lectotype car., BMNH no. 81.5.22, $0.39 \mathrm{~mm}$. Distribution. Widely distributed in tropical sublittoral environments across the Indo-Pacific (except eastern Pacific) and Australia. Believed to have been transported by passive dispersal by ships (Witte \& van Harten, 1991; Witte, 1993), like $K$. demissa, into the Caribbean and Atlantic. Fossil records are: Miocene-Pleistocene of Midway Island; Neogene of the Andaman Islands and Quaternary of the Solomon Islands.

Remarks. One of us (RCW) has seen SEM illustrations of the type species of Kotoracythere (K. abnorma Ishizaki, 1966), kindly provided by Dr Ishizaki. These demonstrate clearly that Morkhovenia is congeneric and, by priority, a junior synonym.

Family Trachyleberididae Sylvester-Bradley, 1948

Subfamily Trachyleberidinae Sylvester-Bradley, 1948 Genus Cletocythereis Swain, 1963

Cletocythereis rastromarginata (Brady, 1880) (Pl. 3, figs 5-9)

1880 Cythere rastromarginata $\mathrm{sp}$. nov. Brady (pars): 82, pl. 16, fig. $2 \mathrm{a}-\mathrm{d}$ (non fig. 1a-d).

1967 Cythere rastromarginata Brady; McKenzie (pars): pl.13, fig. 2.

1967 Cletocythereis bradyi sp. nov. Holden: 40, text-fig. 31a-c. 1972 Cletocythereis rastromarginata (Brady); Benson: 112, pl. 3 (lectotype).

1976 Cythere rastromarginata Brady; Puri \& Hulings: 286, pl. 9, figs 9-14 (lectotype, figs 10-14; paralectotype, fig. 9).

1976 Cletocythereis bradyi Holden; Holden: 28, pl. 4, fig. 13. 1980 Cletocythereis rastromarginata (Brady); Malz: 389, pl. 1, figs 5-7; pl. 2, figs 8-13.

1981 Cletocythereis rastromarginata (Brady); Hartmann: 108, pl.5, figs 15,16 .

1984 Cletocythereis sp. cf. C. bradyi Holden; Titterton MS: 461, pl. 15, fig. 4; pl. 53, figs 10-17.

1987 Cletocythereis rastromarginata (Brady); Yassini \& Jones: 824, figs 4.5-4.7.

1988 Cletocythereis rastromarginata (Brady); Watson MS: 233, pl. 44, figs 7, 10 (=lectotype); figs 8, 9 (=paralectotype).

1990 Cletocythereis rastromarginata (Brady); McKenzie, Reyment \& Reyment: 20, pl. 6, fig. 9.

1995 Cletocythereis rastromarginata (Brady); Yassini \& Jones: 355, figs 375, 377, 379, 381.

non 1988 Cletocythereis rastromarginata (Brady); Watson MS: 233, pl. 44, figs 1-6 [=C. watsonae Jellinek, 1993].

non 1991 Cletocythereis rastromarginata (Brady); Behrens: 50, pl. 12, figs 1-m [=C. watsonae Jellinek, 1993].

non 1994 Cletocythereis sp. cf. C. rastromarginata (Brady); Neil: pl. 1, fig. 10; pl. 2, figs 1, 2.

non 1995 Cletocythereis rastromarginata (Brady); Whatley \& Roberts: 360, fig. 26. [=C. watsonae Jellinek, 1993]

Diagnosis. Subrectangular in shape in lateral view, hastate in dorsal view; ventrolateral alae well developed. Surface of valves 

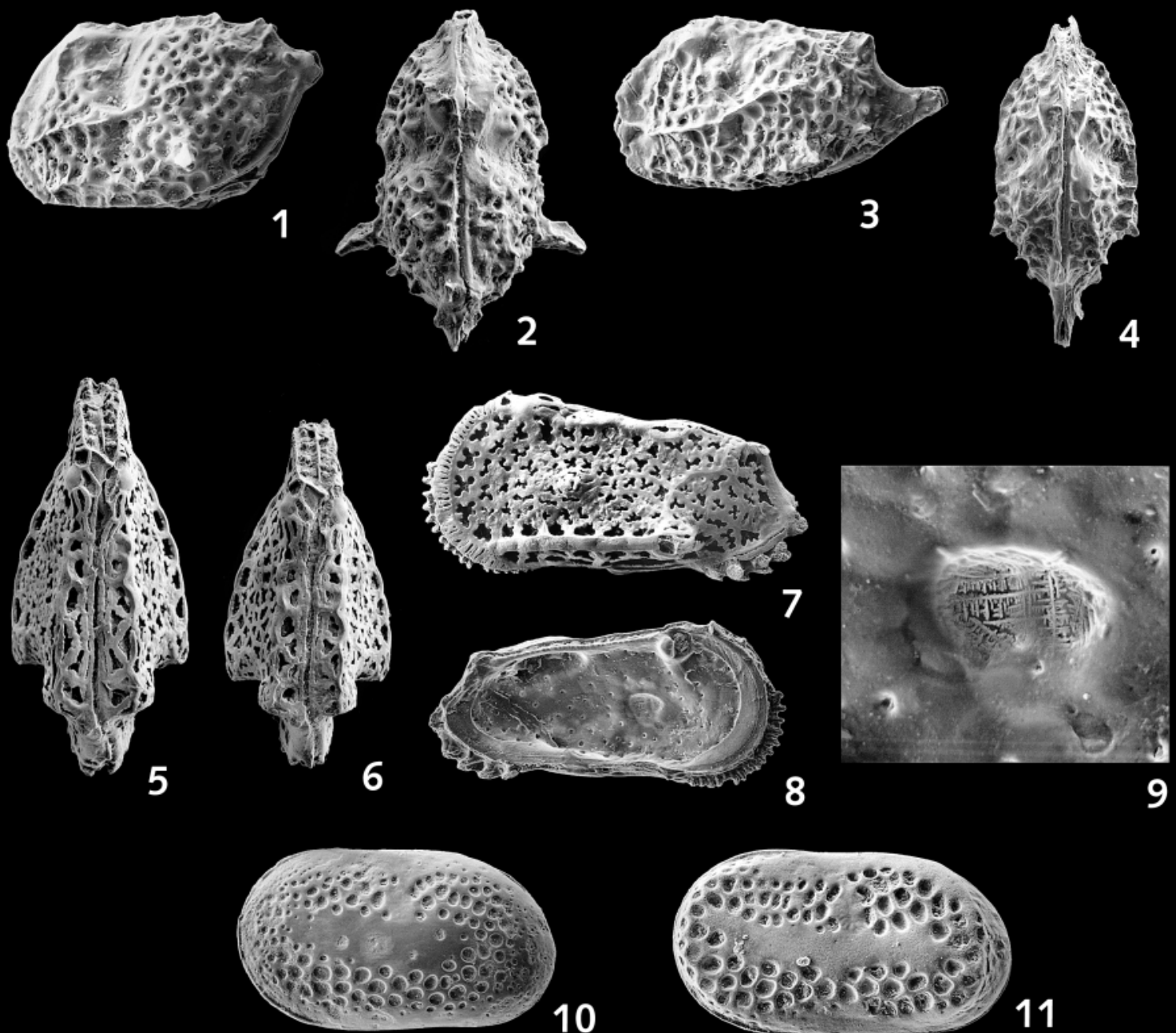

10
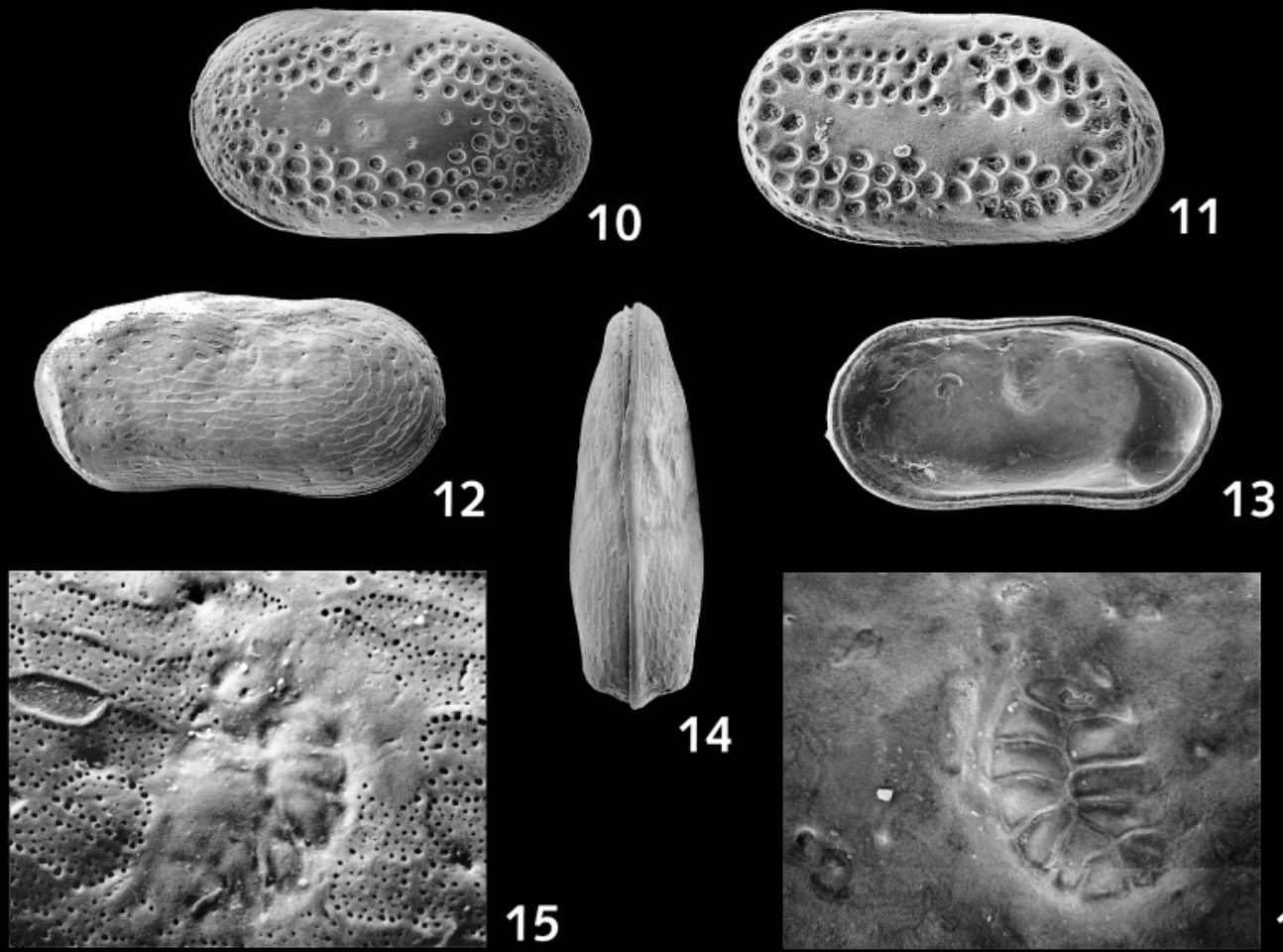
reticulate, concentric about a small subcentral tubercule; small pointed ingrowths so fossae are stellate. Broad anterior rim of densely spaced, small, deep fossae. Short, strong posteroventral marginal ridge. Strong rib along crest of ventrolateral alae, crossed by reticulae so appearing nodose on anterior half. Inner lamella moderately wide, avestibulate.

Lectotype. LV, BMNH no. 80.38.105, designated by Benson (1972, p. 112).

Material. All the material is from Honolulu and is exclusively the alate form: BMNH nos. 1974.335-337, topotypes, 3 cars.; BMNH nos. 1988.383-385, ex slide no. 80.38.104, paralectotypes, 3 cars.; BMNH no. 80.38.105, lectotype, LV; HM nos. 2.09.25, 2.09.26.

Type locality. Honolulu, Hawaii, Recent, dredged at 40 fathoms, off reefs. The information on localities given by Brady (1880; see below) must be wrong. All the extant types are from Honolulu and all are alate.

Dimensions. Length: lectotype $\widehat{\jmath} \mathrm{LV}, \mathrm{BMNH}$ no. 80.38.105, $0.77 \mathrm{~mm}$; paralectotype ô car., BMNH no. $1988.384,0.77 \mathrm{~mm}$; paralectotype + car., BMNH no. 1988.383, $0.68 \mathrm{~mm}$.

Distribution. Pleistocene of Midway Island and SubRecent? of the Hawaiian Islands (Holden, 1967). Recent off Hawaii, the Solomon Islands and the eulittoral of the coast of southeast Australia.

Remarks. Brady (1880) figured two forms of a new species, Cythere rastromarginata: an alate form which he thought to be a female and a non-alate form which he considered to be male. Brady did not designate a holotype and his syntypes were said to come from 'males' (non-alate), recovered from 'reefs off Honolulu' and from off east Moncoeur Island in the Bass Strait, east of New Zealand, and the alate females from west of North Island, New Zealand.

Holden (1967) believed, correctly, that Brady had mistakenly equated the alate and non-alate forms as separate sexes of the same species. Since Brady's original description was based upon the non-alate form, Holden decided that this should retain the name rastromarginata and that the alate form should be designated as a new species Cletocythereis bradyi. Unfortunately, Holden did not designate a lectotype of rastromarginata himself. This was done by Benson (1972), who selected an alate form from 'off reefs at Honolulu'; Puri \& Hulings (1976) re-illustrate this lectotype and also figure an alate paralectotype. This action, therefore, renders $C$. bradyi a junior objective synonym of C. rastromarginata. Had Holden (1967) himself seen Brady's material he would have noted that all the specimens from off Honolulu were alate and that Brady had made a mistake concerning his syntype localities.
Family Schizocytheridea Mandelstam, 1960

Genus Neomonoceratina Kingma, 1948

Neomonoceratina entomon (Brady, 1890)

(Pl. 3, figs 1-4)

1890 Cytherura entomon sp. nov. Brady: 509, pl.3, figs 26, 27, $27 \mathrm{a}$.

1954 Paijenborchella (Neomonoceratina) entomon (Brady); Keij: 358, pl. 3, figs 10-11.

1963 Neomonoceratina entomon (Brady); Van Morkhoven: 371, figs $611-613$.

1984 Neomonoceratina sp. cf. N. entomon (Brady); Titterton MS: 445, pl. 14, figs 13-15; pl. 53, figs 1-7.

1986 Neomonoceratina entomon (Brady); McKenzie: pl. 2, fig. 4 (lectotype).

1988 Neomonoceratina entomon (Brady); Watson MS: 219, pl. 42, figs 5-8.

1988 Neomonoceratina entomon (Brady); Zhao \& Whatley: 571, pl. 2, fig. 16.

1997 Neomonoceratina cf. N. entomon (Brady); Dewi: 59, figs $48-50$.

Diagnosis. A species of Neomonoceratina with 2 ventral, delicate, sinuous ridges from posteroventral spine to anterior, a median ridge across median sulcus. Intercostate areas strongly reticulate and anteroventral margin with narrow flange. Dimorphic, male more elongate and less inflated with median rather than subdorsal caudal process and less well developed posteroventral spine.

Lectotype. Carapace, HM no. 1.15.16, designated by McKenzie (1986, pl. 2, fig. 4) (erroneously listed by him as HM no. B461, see Davis \& Horne, 1988).

Material. HM slide no. 1.15.16, lectotype. HM slide no. 2.14.04, also from Nouméa, New Caledonia, contains 3 carapaces, 2 of which are designated paralectotypes (renumbered 1.15.23, 1.15.24). HM slide no. 2.14.17, Sava Sava Bay, Vanua Levu, Fiji, Recent, at 4 fathoms, fine coral sand - contains a single specimen.

Type locality. Port of Nouméa, New Caledonia, Recent at 3-6 fathoms.

Dimensions. Length: lectotype +car., HM no. 1.15.16, c. $0.48 \mathrm{~mm}$; paralectotype $q$ car., $\mathrm{HM}$ no. $1.15 .24,0.45 \mathrm{~mm}$; paralectotype $\odot$ car., HM no. 1.15.23, $0.47 \mathrm{~mm}$; paralectotype $\widehat{\sigma}$ car., HM no. $1.15 .25,0.48 \mathrm{~mm}$.

Distribution. The species is of common occurrence in Indonesian waters. It also occurs in the Solomon islands, New Caledonia and Fiji.

Remarks. The material of Titterton MS and Watson MS, from the Solomon Islands and the Java Sea respectively, differ slightly

\section{Explanation of Plate 3}

Figs 1-4. Neomonoceratina entomon (Brady, 1890): 1, 2, paralectotype (Hancock Museum no. 1.15,24, ex slide 2.14.04), ㅇ carapace, external view of LV and dorsal view, respectively; 3, 4, paralectotype (Hancock Museum no. 1.15,25, ex slide 2.14.04). ô carapace, external view of LV and dorsal view, respectively; all $\times 85$. From Port of Nouméa, New Caledonia. Figs 5-9. Cletocythereis rastromarginata (Brady, 1880): 5, paralectotype (BMNH no. 1988.384, ex slide 80.38.104), ô carapace, dorsal view; 6, paralectotype (BMNH no. 1988.383, ex slide 80.38.104), + carapace, dorsal view; 7-9, lectotype (BMNH no. 80.38.105), ô LV external and internal views, and detail of muscle scars, respectively; 5-7, $\times 62,8, \times 56,9, \times 275$. From off reefs at Honolulu, Hawaii. Figs 10, 11. Cytherella semitalis Brady, 1868: 10, paralectotype (Hancock Museum no. 1.58.37, ex slide 2.05.34), ô LV external view; 11, lectotype (Hancock Museum no. 1.58.36, ex slide 2.05.34), $\&$ LV external view; both $\times 76$. From Port Pamalang, Java. Figs 12-16. Cytherelloidea venusta (Brady,1880): 12, 13, 15, 16, lectotype (BMNH no. 80.38.180), RV external and internal views, external detail of ornament over central muscle scar area and internal details of muscle scars, respectively; 14, paralectotype (BMNH no.1988.382, ex slide 1961.12.4.1), carapace, dorsal view; 12, $\times 56, \mathbf{1 3}, \times 54, \mathbf{1 4}, \times 62, \mathbf{1 5}, \mathbf{1 6}, \times 250$. From off reefs at Honolulu, Hawaii. 
from the type material in that they possess a small, crenulate postero-dorsal rib.

\section{Suborder Platycopina Sars, 1866 \\ Family Cytherellidae Sars, 1866 \\ Genus Cytherella Jones, 1849 \\ Cytherella semitalis Brady, 1868 \\ (P1. 3, figs 10, 11)}

1868 Cytherella semitalis sp. nov. Brady: 72, pl. 18, figs 23, 24. 1880 Cytherella semitalis Brady; Brady: 175, pl. 44, fig. 2a-e. 1890 Cytherella semitalis Brady; Brady: 517, 521.

1916 Cytherella semitalis Brady; Fyan: 1214, figs 15,16.

1941 Cytherella semitalis Brady; Chapman: 204.

1948 Cytherella leyroyi sp. nov. Kingma: 62, pl. 6, fig. 2a, b.

1948 Cytherella semitalis Brady; Kingma: 63, pl. 6, fig. 6a, b.

1978 Cytherella sp. cf. C. semitalis Brady; Jain: 90, fig. 2a.

1988 Cytherella semitalis Brady; Whatley \& Zhao: 334, pl. 1, figs $7-10$.

1988 Cytherella semitalis Brady; Taylor MS: 120, pl. 8, figs 17, 18. 1988 Cytherella semitalis Brady; Titterton \& Whatley: 770, textfig. 14.

1989 Cytherella semitalis Brady; Howe \& Mckenzie: 4, fig. 37. 1989a Cytherella semitalis Brady; Zhao \& Whatley: 186.

1992 Cytherella semitalis Brady; Mostafawi:133, pl. 1, fig. 4.

1993 Cytherella semitalis Brady; Yassini, Jones \& Jones: 383, pl. 1, figs 14-16; pl. 8, fig. 156.

1995 Cytherella semitalis Brady; Whatley, Cooke \& Warne: 72, pl. 1, figs $1-4$.

1997 Cytherella semitalis Brady; Dewi: 55, figs 11-13.

non 1984 Cytherella semitalis Brady; Titterton MS: 546, pl. 62, figs 9-17.

Diagnosis. Adults conspicuously dimorphic; female strongly inflated posteriorly and wider than male. Surface of valves with large, deep fossae around a smooth, elongate median and muscle scar area; not extending to margins except anteriorly and posteriorly where fossae are smaller, weaker and more dense. Size of fossae varies between individuals but there are essentially 3 rows both dorso- and ventro-medianly.

Lectotype. + RV, HM no. 1.58.36 (ex slide 2.05.34).

Material. HM slide no. 2.05.34, labelled 'Port Pamalang, Java', contains 6 specimens, 3 valves of which are $C$. semitalis, the other 3 of Cythere cancellata. BMNH slide nos. 80.38.178, 80. 38. 179 (locality not recorded) contain 2 specimens, one may be C. semitalis, the other is a Cytherelloidea.

Type locality. North-Watcher Island, north of Java.

Dimensions. Length: lectotype + LV, HM no. 1.58.36, $0.54 \mathrm{~mm}$; paralectotype ô LV, HM no. 1.58.37 (ex slide 2.05.34), $0.51 \mathrm{~mm}$. Distribution. Pliocene of Timor and Sumatra. Recent of India, Indonesia, Singapore, Borneo, northern and eastern Australia and Papua New Guinea.

Genus Cytherelloidea Alexander, 1929

$$
\text { Cytherelloidea venusta (Brady, 1880) }
$$

(Pl. 3, figs 12-16)

1880 Cytherella venusta sp. nov. Brady: 176, pl. 28, fig. 4a-d. 1976 Cytherella venusta Brady; Puri \& Hulings: 313, pl. 24, figs 11-13 (lectotype).

Diagnosis. A species of Cytherelloidea possessing a weak, delicate ornament with polygonal fossae aligned concentric to margins. The solae of the fossae comprise a dense, secondary punctatation.

Lectotype. + RV, BMNH no. 80.38.180.

Material. BMNH slide no. 80.38.180 contains the lectotype designated by Puri \& Hulings (1976); it was a slide that supposedly also originally contained a male and a juvenile valve. A paralectotype, a male carapace (BMNH no. 1988.382, ex slide 1961.12.4.11), was also designated by them.

Type locality. Honolulu, Hawaii, 40 fathoms, off reefs. Recent Dimensions. Length: lectotype $q \mathrm{RV}, \mathrm{BMNH}$ no. 80.38.180, $0.71 \mathrm{~mm}$; paralectotype ô car., BMNH no. 1988.382, $0.65 \mathrm{~mm}$. Distribution. Recorded only from type locality.

Remarks. Cytherelloidea sp. aff. C. venusta of Titterton (1984 MS) from the Recent of Guadalcanal, Solomon Islands and of Whatley \& Keeler (1989) from St Pierre Harbour, Réunion Island differ in possessing a more deeply etched reticulation marginally. Cytherelloidea sp. aff. venusta Watson, 1988 MS, from the Java Sea possesses a crenulate posterior margin, the posterior extremity is above mid-height and the delicate polygonal fossae are less elongate.

\section{POSTSCRIPT}

The Aberystwyth Micropalaeontology Collections together with copies of associated MSc and PhD theses - including those of Hughes (1977), Keeler (1981), Taylor (1988), Titterton (1984), Watson (1988) and Williams (1980), listed above - have now been transferred to the Department of Palaeontology, The Natural History Museum, London.

\section{ACKNOWLEDGEMENTS}

The authors wish to thank the authorities of the Hancock Museum, Newcastle-upon-Tyne and the Department of Zoology, The Natural History Museum, London, for permission to borrow and re-photograph the material described here. The SEM photographs were taken by one of us (JEW), the plates being digitized and much improved by Harry Taylor of The Natural History Museum. One of the referees, J.-F. Babinot, is thanked for his careful reading of the manuscript and suggestions for improvements.

\section{Manuscript received 18 May 2000 \\ Manuscript accepted 26 January 2001}

\section{REFERENCES}

Alexander, C. I. 1929. Ostracoda of the Cretaceous of north Texas. University of Texas Bulletin, 2907: 1-137.

Apostolescu, V. 1956. Contribution à l'étude des ostracodes de l'Eocène inférieur (s.l.) du Bassin de Paris. Revue de l'Institut Français du Pétrole et Annales des Combustibles Liquides, 11: 1327-1352.

Babinot, J.-F. \& Colin, J.P. 1976. Sarlatina nov. gen. (ostracode): sa position dans l'évolution de Cyprideidini Kollmann, 1960. Abhandlungen und Verhandlungen der Naturwissenschaftliche Verein in Hamburg, (N.F.), 18/19(supplement): 161-174. (Proceedings of the 5th International Symposium on Ostracoda, Hamburg, 1974.).

Babinot, J.-F. \& Degaugue-Michalski, F. 1996. Lagoonal to reefal ostracod assemblages from Holocene and Recent deposits, Chesterfield Islands and northern New Caledonia (southwestern Pacific). Micropaleontology, 42: 351-362.

Babinot, J.-F. \& Kouyoumontzakis, G. 1995. Associations d'ostracodes d'un environment récifal envasé: le lagon de L'île de Mayotte (Archipel des Comores, Océan Indien occidental). Geobios, 18: 17-38. 
Behrens, P. 1991. Ostracoda (Crustacea) from Lizard Island, northern Great Barrier Reef, Australia. Families: Cytherellidae, Loxoconchidae, Cytherideidae, Cytheruridae, Paracytherideidae, Pectocytheridae, Krithidae, Cytheromatiidae, Bythocytheridae, Cytheridae. Helgoländer Wissenschaftliche Meeresuntersuchungen, 45: 107-142.

Benson, R. H. 1972. The Bradleya problem. With descriptions of two new psychrospheric ostracode genera, Agrenocythere and Poseidonamicus (Ostracoda: Crustacea). Smithsonian Contributions to Paleobiology, 12: 1-138.

Bonaduce, G., Masoli, M. \& Pugliese, N. 1976. Ostracoda from the Gulf of Aqaba (Red Sea). Pubblicazioni della Stazione Zoologica di Napoli, 490: $372-428$.

Brady, G. S. 1866. On new and imperfectly known species of marine Ostracoda. Transactions of the Zoological Society of London, 5: 359-393.

Brady, G. S. 1868. Ostracoda. In De Folin, L. \& Perier, L. (Eds), Les Fonds de la Mer Volume 1. Savy, Paris.

Brady, G. S. 1880. Report on the Ostracoda dredged by HMS Challenger during the years 1873-1876. Report of the Scientific Results of the Voyage of HMS Challenger, 1873-1876 (Zoology), 1 (pt. 3): $1-184$.

Brady, G. S. 1890. On Ostracoda collected by H.B. Brady, Esq., LL.D., F.R.S. in the South Sea Islands. Transactions of the Royal Society of Edinburgh, 35: 489-525.

Cabioch, G., Anglada, R. \& Babinot, J.-P. 1986. Microfaunes et paléoenvironements des récifs frangeants quaternaires de Mamié et Ricaudy (Nouvelle-Caledonie). Cahiers de Micropaléontologie (New Series), 1: 5-36.

Chapman, F. 1902a. On some Ostracoda from Funafuti. Journal of the Linnean Society of London (Zoology), 28: 417-434.

Chapman, F. 1902b. On some Foraminifera and Ostracoda from Cocos Keeling Atoll, collected by Dr C. W. Andrews, 1898. Proceedings of the Zoological Society of London, 1: 228-233.

Chapman, F. 1910a. On the Foraminifera and Ostracoda from soundings (chiefly deep-water) collected round Funafuti by HMS Penguin. Journal of the Linnean Society, 30: 388-444.

Chapman, F. 1910b. A study of the Batesford Limestone. Proceedings of the Royal Society of Victoria (New Series), 22: 263-314.

Chapman, F. 1915. Report on the Foraminifera and Ostracoda. Zoological Results of the Fishing Experiments carried out by the F.I.S. Endeavour, 1909-1914, 3: 34-55.

Chapman, F. 1919. Ostracoda from soundings obtained during the cruises of the S.Y. Aurora. Scientific Reports of the Australasian Antarctic Expedition, 1911-1914 (Series C, Zoology \& Botany), 5 (pt. 7): 5-48.

Chapman, F. 1941. Report on foraminiferal soundings and dredgings of the F.I.S. Endeavour along the continental shelf of the south east coast of Australia. Transactions of the Royal Society of South Australia, 65: $145-211$.

Chapman, F. \& Crespin, I. 1928. Description of Ostracoda. In Chapman, F. (Ed.), The Sorrento Bore, Mornington Peninsula. Record of the Geological Survey of Victoria, 5, 5-195.

Davis, P. S. \& Horne, D. J. 1988. A note on some type specimens of G.S. Brady's South Sea island ostracods. Journal of Micropalaeontology, 7: $41-42$.

De Deckker, P. \& Jones, P. J. 1978. Checklist of Ostracoda recorded from Australia and Papua New Guinea 1845-1973. Report of the Bureau of Mineral Resources, Geology and Geophysics, Australia, 195: $1-184$.

Dewi, K. T. 1997. Ostracoda from the Java Sea, west of Bawean Island, Indonesia. Marine Geological Institute, Special Publication, 4: 1-86.

Fyan, E. C. 1916. Eenige jong-pliocene Ostracoden van Timor. Proceedings of the Section of Sciences, Koninklijke Nederlandse Akademie van Wetenschappen te Amsterdam, 24: 1175-1186.

Gou, Yunsian, Zheng, Shuying \& Huang, Baoren 1983. Pliocene ostracode fauna of Leizhou Peninsula and northern Hainan Island, Guangdong Province. Palaeontologica Sinica (New Series), 18: 1-134.

Guha, D. K. 1968. On the Ostracoda from Neogene of Andaman Islands. Journal of the Geological Society of India, 9: 58-66.
Hartmann, G. 1974. Die Ostracoden des Untersuchungebietes. Mitteilungen aus den Hamburgischen Zoologischen Museum und Institut, 72: 229-520.

Hartmann, G. 1978. Zur Kenntnis des Eulitorals der australischen Küsten unter besonderer Berucksichtigung der Polychaeten und Ostracoden. Teil 1. Die Ostracoden der Ordnung Podocopida G.W. Müller, 1894 der tropisch-substropischen Westküste Australiens (zwischen Derby in Norden und Perth im Suden). Mitteilungen aus den Hamburgischen Zoologischen Museum und Institut, 75: 63-219.

Hartmann, G. 1980. Teil 5. Die Ostracoden der Ordnung Podocopida G.W. Müller, 1894 der warmtemperierten und subtropisch-tropischen Küstenabschnitte der Süd- und Südostküste Australiens (zwischen Ceduna im Westen and Lakes Entrance in Ostem). Mitteilungen aus den Hamburgischen Zoologischen Museum und Institut, 77: 111-204.

Hartmann, G. 1981. Teil 7. Die Ostracoden der Ordnung Podocopida G.W. Müller, 1894 der subtropisch-tropischen Ostküste Australiens (zwischen Eden im Süden und Heron-Island im Norden). Mitteilungen aus den Hamburgischen Zoologischen Museum und Institut, 78: 97-149.

Holden, 1967. Late Cenozoic ostracodes from the drowned terraces of the Hawaiian Islands. Pacific Science, 21: 1-50.

Holden, J. C. 1976. Late Cenozoic Ostracoda from Midway Island drill holes. United States Geological Survey Professional Paper, 680-F: $1-43$.

Hornibrook, N. de B. 1952. Tertiary and Recent marine Ostracoda of New Zealand. Palaeontological Bulletin, New Zealand Geological Survey, Wellington, 18: 1-82.

Hornibrook, N. de B. 1953. Some New Zealand Tertiary marine Ostracoda useful in stratigraphy. Transactions of the Royal Society of New Zealand, 81: 303-311.

Howe, H. V. \& McKenzie, K. G. 1989. Recent marine Ostracoda (Crustacea) from Darwin and North-Western Australia. Northern Territory Museum of Arts and Sciences, Monograph Series, 3: 1-50.

Hughes, G. W. 1977. MS. The Geology and Foraminiferal Micropalaeontology of the Lungaa and Itina Basin Areas of Western Guadalcanal, Solomon Islands. $\mathrm{PhD}$ thesis. University College of Wales, Aberystwyth, 401pp.

Hussein, S. M. 1998. Recent benthic Ostracoda from the Gulf of Mannar off Tuticornin, southeast coast of India. Journal of the Palaeontological Society of India, 43: 1-22.

Ishizaki, K. 1963. Japanese Miocene ostracodes from the Sunokosaka Member of the Yatsuo Formation, east of Kanazawa City, Ishokawa Prefecture. Japanese Journal of Geology and Geography, 34: 19-34.

Ishizaki, K. 1966. Miocene and Pliocene ostracodes from the Sendai area, Japan. Science Reports of the Tohoku University, Sendai (Series 2, Geology), 37: 131-163.

Ishizaki, K. 1968. Ostracodes from Ouranouchi Bay, Kochi Prefecture, Japan. Science Reports of the Tohoku University, Sendai (Series 2, Geology), 40: 1-45.

Jain, S. P. 1978. Recent Ostracoda of Mandvi Beach, west coast of India. Bulletin of the Indian Geologists Association, 11: 89-139.

Jellinek, T. 1993. Zur Okologie und Systematik rezenter Ostracoden aus dem Bereich des Kenianischen Barriere Riffs. Senckenbergiana Lethaea, 73: 83-225.

Jones, T. R. 1849. A monograph of the Entomostraca of the Cretaceous Formation of England. Monograph of the Palaeontographical Society, 1849: $1-41$.

Keeler, N. 1981. MS. Recent Podocopid Ostracoda from Agulhas Bank, South African Continental Margin and Reunion Island, Southern Indian Ocean. MSc thesis. University College of Wales, Aberystwyth.

Keij, A. J. 1954. Some Recent Ostracoda of Manila (Philippines). Proceedings, Koninklijke Nederlandse Akademie van Wetenschappen (Section B), 57: 351-363.

Keij, A. J. 1957. Eocene and Oligocene Ostracoda from Belgium. Mémoires de l'Institut Royal des Sciences Naturelle de Belgique, 136: $1-210$.

Kingma, J. T. 1948. Contributions to the Knowledge of the YoungCaenozoic Ostracoda from the Malayan Region. Doctoral Dissertation. University of Utrecht, 118pp.

Kollmann, K. 1960. Cytherideinae und Schulerideinae n. subfam. (Ostracoda) aus dem Neogen des östl. Oesterreich. Mitteilungen der Geologischen Gesellschaft in Wien, 51 (for 1958): 89-195. 
Maddocks, R. F. 1969. Recent ostracodes family Pontocyprididae chiefly from the Indian Ocean. Smithsonian Contributions to Zoology, 7: $1-56$.

Maddocks, R. F. 1977. Anatomy of Australoecia (Pontocyprididae, Ostracoda). Micropaleontology, 23: 206-215.

Maddocks, R. F. 1990. Living and fossil Macrocyprididae (Ostracoda). Paleontological Contributions, University of Kansas, Monograph, 2: $1-404$.

Maddocks, R. F. 1991. Revision of the family Pontocyprididae (Ostracoda), with new anchialine species and genera from the Galapagos Islands. Zoological Journal of the Linnean Society, 103: 309-333.

Malz, H. 1980. Cletocythereis Swain, 1963 (Ostracoda) besondere Merkmale und geographische Verbreitung ihrer Artung. Senckenbergiana Lethaea, 60: 381-397.

Malz, H. \& Ikeya, N. 1986. Miocyprideis and Bishopina, related but different cyprideidine Ostracoda. Reports of the Faculty of Science, Shizuoka University, 20: 175-187.

McKenzie, K. G. 1967. Recent Ostracoda from Port Phillip Bay, Victoria. Proceedings of the Royal Society of Victoria, 80: 61-106.

McKenzie, K. G. 1986. A comparative study of collections from the S.W. Pacific (Saipan to Tonga during the years 1873-1876.), with the descriptions of Gambiella caudata (Brady, 1890) and a new species of Pterobairdia (Ostracoda). Journal of Micropalaeontology, 5 (pt. 1): 91-108

McKenzie, K. G., Reyment, R. A. \& Reyment, E. R. 1990. Pleistocene and Recent Ostracoda from Goose Lagoon Drain, Victoria and Kingston, South Australia. Bulletin of the Geological Institution of the University of Uppsala (New Series), 16: 1-46.

Mostafawi, N. 1992. Rezente Ostracoden aus dem mittleren Sunda-Schelf, zwischen der Malaiischen Halbinsel und Borneo. Senckenbergiana Lethaea, 72: 129-168.

Neil, J. V. 1994. Miocene Ostracoda of the Trachyleberididae and Hemicytheridae from the Muddy Creek area, south-western Victoria. Memoirs of the Museum of Victoria, 54: 1-49.

Okubo, I. 1979. Two species of Propontocypris (Ostracoda) from the Inland Sea of Japan. Proceedings of the Japanese Society of Systematic Zoology, 17: 31-37.

Puri, H. S. \& Hulings, N. C. 1976. Designation of lectotypes of some ostracods from the Challenger Expedition. Bulletin of the British Museum (Natural History) (Zoology), 29: 251-315.

Sars, G. O. 1866. Oversigt af Norges marine Ostracoder. Forhandlinger $i$ Videnskabsselskabet $i$ Kristiania, for, 1865: 1-130.

Scott, A. 1905. Report on the Ostracoda Supplementary Report upon the Marine Biology of Ceylon, no. 22, pp. 365-384. [Part of: Herdman, W.A. Report to the Government of Ceylon on the Pearl Oyster Fisheries in the Gulf of Manaar].

Shyam Sunder, V. V., Varma, K. U. \& Naidu, T. Y. 1995. Recent Ostracoda of the Goguleru Creek, east coast of India. Journal of the Geological Society of India, 45: 471-481.

Sylvester-Bradley, P. C. 1947. Some ostracod genotypes. Annals and Magazine of Natural History (Series 11), 13: 192-199.

Taylor, A. 1988. MS. The Taxonomy, Ecology and Zoogeographical Significance of Recent Reef Ostracoda from Singapore. MSc thesis. University of Wales, Aberystwyth, 203pp.

Teeter, J. W. 1973. Geographic distribution and dispersal of some Recent shallow-water Ostracoda. Ohio Journal of Science, 73: 46-54.

Teeter, J. W. 1975. Distribution of Holocene marine Ostracoda from Belize. In Wantland, K. F. \& Pusey, W. C. (Eds), Belize shelf carbonate sediments, clastic sediments and ecology. American Association of Petroleum Geologists. Studies in Geology, 2, 400-499.

Titterton, R. 1984. The Taxonomy, Ecology and Distribution of Recent Ostracoda from the Solomon Islands. PhD thesis. University College of Wales, Aberystwyth, 945pp.

Titterton, R. \& Whatley, R. C. 1988. MS. The provincial distribution of shallow water Indo-Pacific marine Ostracoda. Origin, antiquity, dispersal routes and mechanisms. In Hanai, T., Ikeya, N. \& Ishizaki, K. (Eds), Proceedings of the Ninth International Symposium on Ostracoda. Evolutionary Biology of Ostracoda: its Fundamentals and Applications, 759-787. Elsevier Science Publishers, Amsterdam.
Triebel, E. 1960. Die taxionomische Stellung und die Gattungen der Unterfamilie Macrocypridinae (Ostracoda). Senckenbergiana Biologica, 41: 109-124.

Van Morkhoven, F. P. C. M. 1963. Post-Palaeozoic Ostracoda. Their Morphology, Taxonomy, and Economic Use. Volume 2, Generic Descriptions. Elsevier Publishing Company, Amsterdam, 478pp.

Wang, Pinxian \& Zhao, Quanhong 1985. Ostracod distribution in bottom sediments of the East China Sea. In Wang, Pinxian (Ed.), Marine Micropaleontology of China, 70-92. China Ocean Press, Beijing and Springer-Verlag, Berlin.

Watson, K. A. 1988. MS. The Taxonomy and Distribution of Recent Reef Ostracoda from the Palau Seribu, Java Sea. PhD thesis. University of Wales, Aberystwyth, 395pp.

Whatley, R. C., Cooke, P. \& Warne, M. 1995. The Ostracoda from Lee Point on Shoal Bay, Northern Australia. Part 1. Cladocopa and Platycopina. Revista Española de Micropaleontología, 27: 69-89.

Whatley, R. C. \& Keeler, N. P. 1989. Ostracodes actuels de l'Île de la Réunion (Sud-Ouest de l'Océan Indien). Revue de Micropaléontologie, 32: 63-84.

Whatley, R. C. \& Roberts, R. 1995. Marine Ostracoda from Pitcairn, Oeno and Henderson Islands. In Benton, T. G. \& Spencer, T. (Eds), The Pitcairn Islands: Biogeography, Ecology and Prehistory. Biological Journal of the Linnean Society, 56, 359-364.

Whatley, R. C. \& Zhao, Quanhong 1987. Recent Ostracoda of the Malacca Straits. Part 1. Revista Española de Micropaleontologia, 29: 327-366.

Whatley, R. C. \& Zhao, Quanhong 1988. A revision of Brady's 1869 study of the Ostracoda of Hong Kong. Journal of Micropalaeontology, 7: 21-29.

Williams, E. U. 1980. MS. Some Quaternary Ostracoda from the Solomon Islands. MSc thesis. University College of Wales, Aberystwyth, 183pp.

Witte, L. 1993. Taxonomy and origin of modern West African shallow marine Ostracoda. Verhandelingen Koniklijke Nederlandse Akademie van Wetenschappen, Afdeeling Natuurkunde (Eerste Reeks), 39: $13-105$.

Witte, L. \& Van Harten, D. 1991. Polymorphism, biogeography, and systematics of Kotoracythere inconspicua (Brady, 1880) (Ostracoda, Pectocytheridae). Journal of Biogeography, 18: 427-436.

Wouters, K. 1981. Two new marine podocopid species from Hansa Bay, Papua New Guinea (Crustacea: Ostracoda). Bulletin de l'Institut Royal de Sciences Naturelles de Belgique (Biologie), 53: 1-12.

Yassini, I. \& Jones, B. G. 1987. Ostracoda in Lake Illawarra: environmental factors, assemblages and systematics. Australian Journal of Marine and Freshwater Research, 38: 795-843.

Yassini, I. \& Jones, B. G. 1995. Recent Foraminiferida and Ostracoda from Estuaries and Shelf Environments on the Southeastern Coast of Australia. University of Wollongong Press, 484pp.

Yassini, I. \& Mikulandra, M. 1989. Mckenziartia and Pectocythere (Pectocytheridae, Ostracoda, Crustacea) in Lake Macquarie, New South Wales. Proceedings of the Linnean Society of New South Wales, 110: $159-174$.

Yassini, I., Jones, B. G. \& Jones, M. R. 1993. Ostracods from the Gulf of Carpentaria, northeastern Australia. Senckengergiana Lethaea, $\mathbf{7 3}$ 375-406.

Zhao, Quanhong, Wang, Pinxian \& Zhang, Qinglan 1985. Ostracoda in bottom sediments of the South China Sea off Guandong Province, China. Their taxonomy and distribution. In Wang, Pinxian (Ed.), Marine Micropaleontology of China, 196-218. China Ocean Press, Beijing and Springer-Verlag, Berlin.

Zhao, Quanhong \& Whatley, R. C. 1988. The genus Neomonoceratina (Crustacea, Ostracoda) from the Cainozoic of the West Pacific margins. Acta Oceanologica Sinica, 7: 562-577.

Zhao, Quanhong \& Whatley, R. C. 1989a. Recent podocopid Ostracoda of the Sedili River and Jason Bay, southeast Malay Peninsula. Micropaleontology, 35: 168-187.

Zhao, Quanhong \& Whatley, R. C. 1989b. A taxonomic revision of the new species of Ostracoda described by J. T. Kingma (1948) from the late Cainozoic of Indonesia. Acta Micropalaeontologica Sinica, 6 : 229-246. 